\title{
INFLUENCE OF SEWAGE SLUDGE ON THE CHOSEN SOIL PROPERTIES AND MICROBIOLOGICAL PARAMETERS OF URBAN GRASS MIXTURES RHIZOSPHERE
}

\author{
Urszula Wydro', Elżbieta Wołejko' ${ }^{1}, T^{1}$ deusz Łoboda', Marzena Matejczyk' ${ }^{1}$, Andrzej Butarewicz' \\ 1 Division of Sanitary Biology and Biotechnology, Bialystok University of Technology, Wiejska 45E, 15-351 \\ Białystok.Poland, e-mail:uwydro@gmail.com; elzbietawolejko@wp.pl; lobodat@vp.pl; m.matejczyk@pb.edu. \\ pl; a.butarewicz@pb.edu.pl
}

Received: 2014.08.14 Accepted: 2014.10 .17 Published: 2015.01.02

\begin{abstract}
The aim of this study was to analyse the influence of municipal sewage sludge on selected microbiological parameters in the rhizosphere of lawn grass mixtures. Four experiments on the lawns along the main roads of Bialystok were founded. The factors in the experiment were three doses of sewage sludge ( 0 - control; 7.5 and $\left.15 \mathrm{~kg} \cdot \mathrm{m}^{-2}\right)$ and two grass mixtures (Eko and Roadside). The studied parameters were monitored twice during 2011 vegetation season by determining the total number of soil microorganisms, the total number of Gram-negative bacteria, the number of bacteria of Pseudomonas fluorescens species, the number of amylolytic and proteolytic bacteria. Sewage sludge amended to soil resulted in a change of physical-chemical properties of soil. The sewage sludge application to soil influenced significantly the number of proteolytic and Gram-negative bacteria.
\end{abstract}

Keywords: sewage sludge, rhizosphere, urban soil, microorganisms.

\section{INTRODUCTION}

Urban soils and green spaces, including lawns, are a crucial component of urban ecosystems, contributing directly or indirectly to the general quality of life of city residents [Luo et al. 2012]. Urban soils are characterized by a distortion of the soil profile, increasing soil $\mathrm{pH}$, salinity (especially street-adjacent areas), low water capacity and water permeability as well as weak biological activity and contamination with heavy metals [Wysocki, Stawicka 2005].

Sewage sludge is an increasingly important economic and environmental problem. According to Central Statistic Office [2013], in 2012 in Poland 533.3 thousand $\mathrm{Mg}$ of dry matter from municipal sewage sludge was produced. It is estimated that from 2018 over 700 thousand $\mathrm{Mg}$ dry matter of sewage sludge will be produced [Bień et al. 2011]. Therefore, it is necesary to look for methods and ways of their rational use.
One way of utilization of municipal sewage sludge is to use it for recultivation of low quality soils and degraded areas [Sanches-Monedero 2004]. It is justified by the fertilizer properties of the sewage sludge, such as high content of nitrogen, phosphorus, carbon, macro- and microelements, which are necessary to improve soil conditions e.g. respiration and enzymatic activity and plant growth [Singh, Agrawal 2008, Siuta 2003]. Therefore, a very promising future area of application of municipal sewage sludge is the land adjacent to roads. In addition, fertilizer components and organic matter from sludge return to the environment.

The rhizosphere zone is an area of intense biological activity, characterized by rich bacterial and fungal flora, which has a large impact on the uptake of nutrients by the roots [Jurkiewicz et al. 2004]. According to Wolińska [2010], microbial activity plays a very important role in the life of plants. Plants form soil microflora and the influence microbial metabolism, constantly take place in the environment. 
The aim of this work is to investigate the impact of sewage sludge fertilization on the number of selected microbiological parameters of lawn grasses mixtures in the rhizosphere and linking these parameters with physico-chemical properties of the soil.

\section{MATERIAL AND METHODS}

Four experiments on the lawns along the main roads of Bialystok: Hetmanska Str., Piastowska Str., Popieluszki Str. and Raginisa Str. were conducted. The factors of the experiment were: three doses of sewage sludge $(0.0$ - control, 7.5 and $15.0 \mathrm{~kg} / \mathrm{m}^{2}$ ) and two mixtures of lawn grasses (Eko and Roadside).

Stabilized municipal sewage sludge from the Municipal Wastewater Treatment Plant in Sokolka was used. In autumn 2010 the test areas were fertilized with municipal sludge with two doses: $7.5 \mathrm{~kg} \times \mathrm{m}^{-2}(14.5 \mathrm{t} / \mathrm{ha}$ of dry matter) and 15.0 $\mathrm{kg} \times \mathrm{m}^{-2}$ and control plots (without sewage sludge) were founded. The doses of sewage sludge were established according to Kiryluk [2002], who found in several years study that the most effective doses for turfing of municipal waste disposal areas were those above $40 \mathrm{t} / \mathrm{ha}$.

Before the establishment of the experiment both sewage sludge and soil from each combination were analyzed according to the Regulation of Ministry of Environment of July $13^{\text {th }}, 2010$ concerning municipal sewage sludge (Table 1 and 2). The obtained values of the studied parameters were compared with the values of the Regulation concerning non-agricultural land recultivation [Directive of... 2010].

In spring 2011, on the prepared plots two mixtures of lawn grasses were seeded, Eko from Nieznanice Plant Breeding Station which included $30 \%$ of Lolium perenne cv. Niga, $15 \%$ of Poa pratensis cv. Amason, 22.6\% of Festuca rubra cv. Adio and $32.4 \%$ of Festuca rubra cv. Nimba, and grass mixture Roadside from Barenbrug which included $32 \%$ of Lolium perenne cv. Barmedia, $5 \%$ of Poa pratensis cv. Baron, 52\% of Festuca rubra rubra cv. Barustic, 5\% of Festuca rubra commutata cv. Bardiva (BE) and 6\% of Festuca rubra commutata $\mathrm{cv}$. Bardiva (NL).

\section{Microbiological analyses}

Rhizosphere soil samples for microbiological analyses were collected two times, in July and October 2011. A fresh sample of $5 \mathrm{~g}$ of grass mixture roots with the soil was suspended in $45 \mathrm{ml}$ of sterile saline solution and shaken for $10 \mathrm{~min}$ and then subjected to dispersion. Subsequently, another ten-fold dilutions $\left(10^{-1}-10^{-6}\right)$ and then the soil samples were inoculated on the surface of Petri dishes in triplicate on:

- $10 \%$ TSA (Tryptic Soy Agar) medium for determining the total number of bacteria [Galimska-Stypa et al. 1999];

- $10 \%$ TSA medium with crystal violet to determine the number of Gram-negative bacteria [Galimska-Stypa et al. 1999];

- King B medium with peptone for determining the number of bacteria of the species Pseudomonas fluorescent [Galimska-Stypa et al. 1999].

- Frazier medium for determining the number of proteolytic bacteria [Rodina 1968];

- Starch agar to determine the number of amylolytic bacteria [Rodina 1968].

The mean number of colonie was expressed as $\mathrm{CFU} \cdot \mathrm{g}^{-1} \mathrm{~d}$.m. soil.

\section{Physico-chemical analysis}

$\mathrm{pH}$ in soil samples taken from a depth of 0-20 cm was determined by the potentiometric

Table 1. Selected physic-chemical properties of soils in research plots at Popieluszki, Hetmanska, Piastowska and Raginisa Streets, taken before the foundation of experience in autumn 2010 (the analyses were done by the Regional Chemical and Agricultural Station in Białystok)

\begin{tabular}{|c|c|c|c|c|c|c|c|c|c|}
\hline \multirow{2}{*}{ Soil samples } & \multirow{2}{*}{$\mathrm{pH}$} & \multirow{2}{*}{$\begin{array}{c}\mathrm{P}_{2} \mathrm{O}_{5} \\
{[\mathrm{mg} / 100 \mathrm{~g}} \\
\text { d.m.] }\end{array}$} & \multicolumn{7}{|c|}{ Heavy metals content in $\mathrm{mg} / \mathrm{kg}$ of $\mathrm{DM}$ of soil } \\
\hline & & & $\mathrm{Cd}$ & $\mathrm{Cu}$ & $\mathrm{Ni}$ & $\mathrm{Pb}$ & $\mathrm{Zn}$ & $\mathrm{Hg}$ & $\mathrm{Cr}$ \\
\hline Popiełuszki Street & 7.6 & 22.0 & 1.7 & 17.9 & 5.9 & 26.5 & 82.4 & 0.14 & 13.1 \\
\hline Hetmanska Street & 7.9 & 7.3 & $<0.5$ & 9.5 & 4.5 & 12.4 & 40.9 & 0.06 & 10.9 \\
\hline Piastowska Street & 7.7 & 18.4 & $<0.5$ & 16.8 & 10.8 & 23.9 & 195 & 0.02 & 13.6 \\
\hline Raginisa Street & 7.4 & 10.0 & $<0.5$ & 8.8 & 4.6 & 12.1 & 36.6 & 0.05 & 8.3 \\
\hline \multicolumn{3}{|c|}{$\begin{array}{l}\text { Limited concentration for land reclamation for } \\
\text { non-agricultural [Directive of ...2010] }\end{array}$} & 3 & 50 & 30 & 50 & 150 & 1 & 100 \\
\hline
\end{tabular}


Table 2. Characteristics of municipal sewage sludge from sewage treatment plants in Sokolka used in experiments (the analyses were done by the Regional Chemical and Agricultural Station in Białystok)

\begin{tabular}{|c|c|c|c|c|c|c|c|}
\hline \multicolumn{8}{|c|}{ The indicators determined in sludge } \\
\hline $\mathrm{pH}$ & 6.7 & \multicolumn{5}{|c|}{ ammonium nitrogen (\% DM) } & 0.1 \\
\hline Dry matter (\%) & 19.3 & \multicolumn{5}{|c|}{ calcium (\% DM) } & 5.5 \\
\hline \multirow[t]{3}{*}{ Total nitrogen (\% DM) } & 4.0 & \multicolumn{5}{|c|}{ magnesium (\% DM) } & 0.7 \\
\hline & \multicolumn{7}{|c|}{ Heavy metals content in $\mathrm{mg} / \mathrm{kg}$ of DM of sewage sludge } \\
\hline & $\mathrm{Cd}$ & $\mathrm{Cu}$ & $\mathrm{Ni}$ & $\mathrm{Pb}$ & $\mathrm{Zn}$ & $\mathrm{Hg}$ & $\mathrm{Cr}$ \\
\hline Metal content in sludge & $<0.5$ & 194 & 22,0 & 23.5 & 1459 & 1.0 & 58 \\
\hline $\begin{array}{l}\text { Limit value in the application of sludge to land reclamation } \\
\text { for non-agricultural purposes [Directive of ...2010] }\end{array}$ & 25 & 1200 & 400 & 1000 & 3500 & 20 & 1000 \\
\hline Viable helminth ova of Ascaris sp., Trichris sp., Toxocara sp. & \multicolumn{7}{|c|}{ not detected } \\
\hline Bacteria of the genus Salmonella in $100 \mathrm{~g}$ of sludge & \multicolumn{7}{|c|}{ not detected } \\
\hline
\end{tabular}

method in distilled water. The total nitrogen was measured with the Kjeldahl method based on wet oxidation of organic matter using $\mathrm{H}_{2} \mathrm{SO}_{4}$ and conversion of organic nitrogen to the ammonium form. The available phosphorus (expressed as $\mathrm{P}_{2} \mathrm{O}_{5}$ ) was determinated by Egner-Riehm method in 0.04 solution of calcium lactate. Nitrogen and phosphorus were determined by UV-vis spectrophotometry. The organic carbon was measured by Tiurin method which is based on the oxidation of organic carbon by potassium dichromate in an acid medium and measurement of the excess dichromate using Mohr's salt [Ostrowska et al. 1991].

\section{Statistical analysis}

To test for the effects of the experimental factors (dose of sewage sludge, sampling time, grass mixture) in the variables analyzed, the tree-way analysis of variance ANOVA with interaction term was performed. In the case of significant F-tests, differences between group means were assessed by the Tukey post hoc test at significance level at $\mathrm{p}<0.05$. The correlation between characteristics was calculated using Spearman's rank correlation (for $\mathrm{n}<50$ ) with the level of significance established at $\mathrm{p}<0.05$ by using Statistica 10.0.

\section{RESULT AND DISCUSSION}

The $\mathrm{pH}$ values for all samples tested ranged from 7.2 to 8.0, which means that at each point alkalinity of the soil occurred (Table 3).

The soil fertilization of sewage sludge caused an increase the content of organic carbon, total nitrogen and available phosphorus in urban soils (Table 3). The average content of organic carbon was smallest in soil without application of sewage sludge with Eko grass mixture (1.3\% d.m.) and largest in the soil samples with double dose of sewage sludge and Eko grass mixture (2.2\% d.m.). The average total content of total nitrogen ranged from $0.30 \%$ d.m. for the control plots with Eko grass mixture to $0.42 \% \mathrm{~d} . \mathrm{m}$. for the double dose of biosolids and Eko grass mixture. The average smallest content of available phosphorus was observed for soil samples for control plots with Eko mixture (13.3 mg/100 g d.m.) and largest for soil with sludge dose $15.0 \mathrm{~kg} / \mathrm{m}^{2}$ and Roadside grass mixture ( $36.5 \mathrm{mg} / 100 \mathrm{~g} \mathrm{~d}$.m.).

The results of this study have shown that the fertilization with sewage sludge evoked changes in rhizosphere of microbiological activity of grass mixture (Figure 1).

The experimental factors did not have a significant effect on this parameter (Figure 1). The average total number of bacteria was the smallest in the soil without application of sewage sludge (13.0 CFU $\times 10^{7} \mathrm{~g}^{-1} \mathrm{DM}$ of soil) with the mixture Eko in samples taken in July, while the largest average total number of bacteria was observed in the samples collected in October with the Eko mixture and the highest dose of biosolids (15 $\left.\mathrm{kg} / \mathrm{m}^{2}\right)\left(41.2 \mathrm{CFU} \times 10^{7} \mathrm{~g}^{-1} \mathrm{DM}\right.$ of soil). Generally, with increasing doses of sludge an increase in the total number of microorganisms was observed. However, soil samples taken in October where Roadside mixture was grown showed an increased number of microorganisms at a dose of $7.5 \mathrm{~kg} / \mathrm{m}^{2}$ (Figure 1).

Studies on the impact of different doses of sewage sludge on the number of Gram-negative bacteria revealed an increase in the number of these microorganisms in rhizosphere with an increase in the biosolids dose (Figure 1). The av- 
Table 3. Selected physico-chemical parameters of soil after application different doses of sewage sludge $(0,7.5,15$ $\mathrm{kg} / \mathrm{m}^{2}$ ) and two lawn grass mixtures (Eko and Roadside) measured in October 2011 (average \pm standard deviation)

\begin{tabular}{|l|c|c|c|c|c|c|c|c|}
\hline \multirow{2}{*}{$\begin{array}{c}\text { Sewage sludge } \\
\text { dose }\left[\mathrm{kg} / \mathrm{m}^{2}\right]\end{array}$} & \multicolumn{2}{|c|}{$\mathrm{pH}_{\mathrm{H} 2 \mathrm{O}}$} & \multicolumn{2}{c|}{$\mathrm{C}_{\text {org }}[\%$ d.m.] } & \multicolumn{2}{c|}{$\mathrm{N}[\%$ d.m.] } & \multicolumn{2}{c|}{$\begin{array}{c}\mathrm{P}_{2} \mathrm{O}_{5} \\
{[\mathrm{mg} / 100 \mathrm{~g}]}\end{array}$} \\
\cline { 2 - 10 } & eko & roadside & eko & roadside & eko & roadside & eko & roadside \\
\hline $0.0(\mathrm{n}=8)$ & $7.7 \pm 0.2$ & $7.6 \pm 0.0$ & $1.3 \pm 0.2$ & $1.4 \pm 0.7$ & $0.30 \pm 0.02$ & $0.33 \pm 0.06$ & $13.3 \pm 6.7$ & $13.3 \pm 8.3$ \\
\hline $7.5(\mathrm{n}=8)$ & $7.6 \pm 0.2$ & $7.5 \pm 0.1$ & $1.8 \pm 0.5$ & $1.8 \pm 0.3$ & $0.31 \pm 0.06$ & $0.33 \pm 0.05$ & $25.1 \pm 13.0$ & $23.3 \pm 11.2$ \\
\hline $15.0(\mathrm{n}=8)$ & $7,4 \pm 0.1$ & $7.4 \pm 0.1$ & $2.2 \pm 0.8$ & $2.0 \pm 0.3$ & $0.42 \pm 0.14$ & $0.36 \pm 0.06$ & $32.6 \pm 10.6$ & $36.5 \pm 9.8$ \\
\hline $\operatorname{MIN}(\mathrm{n}=24)$ & 7.3 & 7.2 & 0.6 & 0.5 & 0.23 & 0.28 & 4.9 & 4.3 \\
\hline $\operatorname{MAX}(\mathrm{n}=24)$ & 8.0 & 7.7 & 3.3 & 2.5 & 0.58 & 0.42 & 45.1 & 47.1 \\
\hline
\end{tabular}

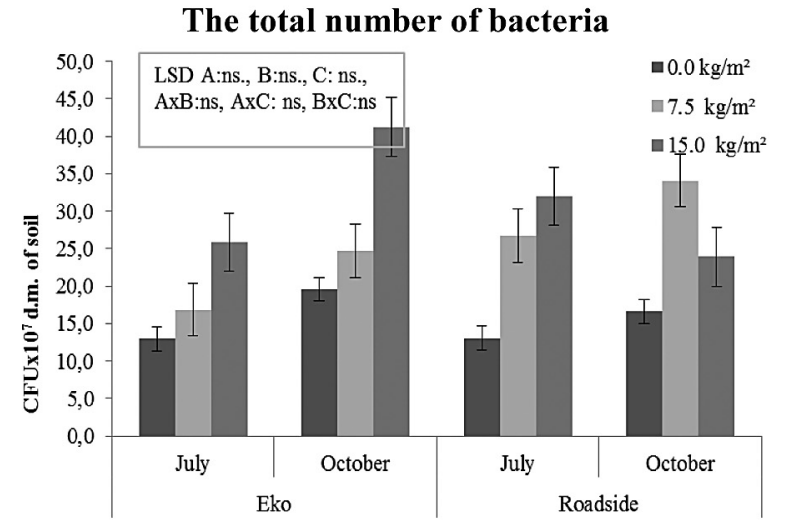

The number of Pseudomonas fluorescens

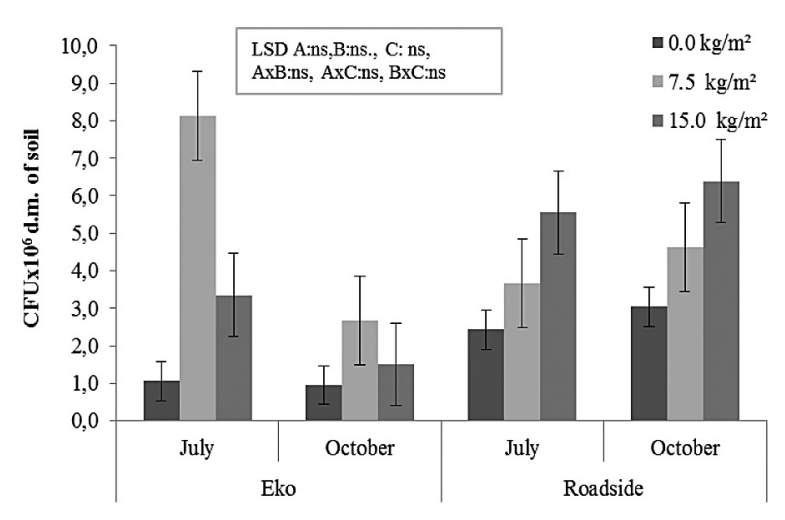

The number of Gram-negative bacteria

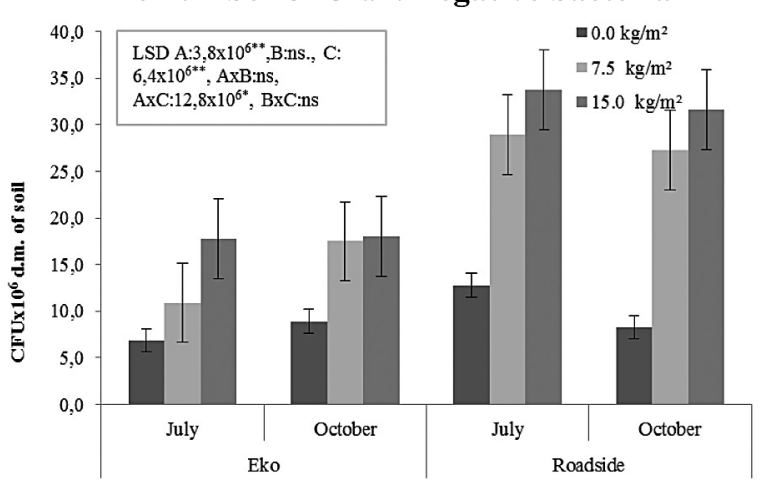

The number of proteolytic bacteria

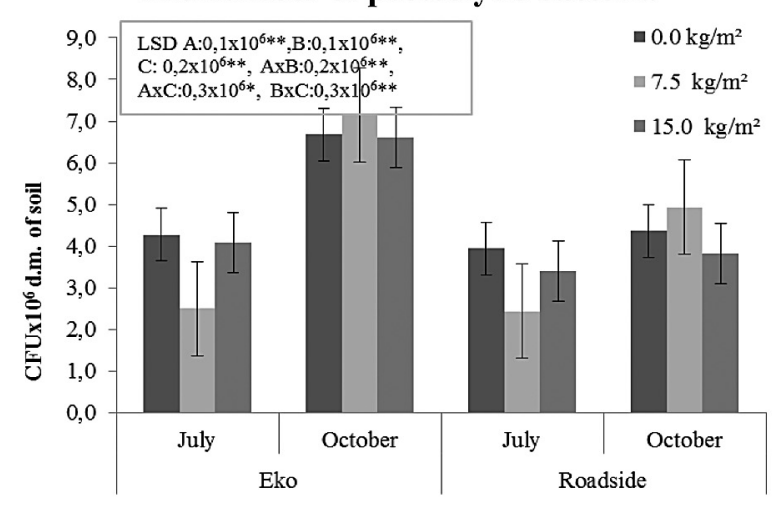

The number of amylolytic bacteria

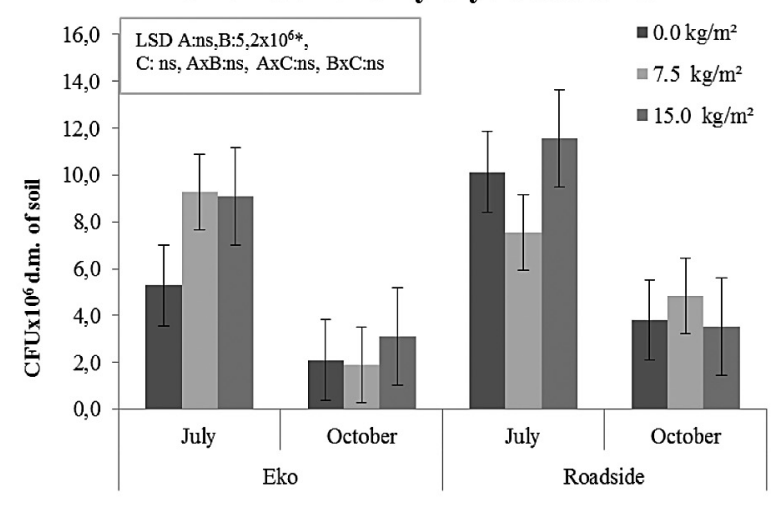

Figure 1. The number of selected bacteria in grass mixtures rhizosphere in samples collected in July and October 2011 after application of different doses of sewage sludge $\left(0,7.5,15 \mathrm{~kg} / \mathrm{m}^{2}\right)$ and two lawn grass mixtures (Eko and Roadside) (A: mixture of grass, B: sampling time, C: dose of sewage sludge, ns - not significant differences, $* *$ significant differences for $\mathrm{p}<0,01$; $*$ for $\mathrm{p}<0,05)$ 
erage largest number of this microbial parameter was found in samples where Roadside grass mixture was grown. The average number of Gramnegative bacteria was largest in the soil samples collected in July with the dose of $15.0 \mathrm{~kg} / \mathrm{m}^{2}$ and Roadside mixture (33.7 CFU $\times 10^{6} \mathrm{~g}^{-1} \mathrm{DM}$ of soil), while the lowest results were obtained for the samples taken in July on the control plots with Eko mixture (6.9 CFU $\times 10^{6} \mathrm{~g}^{-1} \mathrm{~d}$.m. of soil).

The genus Pseudomonas is an important component of the rhizosphere, which developed mechanisms that restrict pathogenic effect of fungi and bacteria. Species from genus of Pseudomonas are know as Plant Growth Promoting Rhizobacteria (PGPR). In addition to the protective function, Pseudomonas can also enrich soil with nutrients, plant hormones and vitamins synthesized and enhance their bioavailability for plants [Jankiewicz 2010].

We found that the number of $P$. fluorescens in soil varied (Figure 1). The experimental factors did not influence the studied parameter. The largest average number of $P$. fluorescens $\left(6.4 \mathrm{CFU} \times 10^{6}\right.$ $\mathrm{g}^{-1}$ d.m. of soil) was observed in the samples taken in October on plots with double dose of sewage sludge and Roadside grass mixture. The smallest number of these microorganisms were obtained in October for the control plots with Eko grass mixture $\left(0.9 \mathrm{CFU} \times 10^{6} \mathrm{~g}^{-1} \mathrm{~d} . \mathrm{m}\right.$. of soil).

Joniec et al. [2012], suggest that sewage sludge represents a rich source of proteins. The obtained results for the number of proteolytic bacteria in grass mixtures rhizosphere shows significant effect of the sewage sludge dose on this parameter (Figure 1). The average largest number of proteolytic bacteria was obtained in October on the plots with $7.5 \mathrm{~kg} / \mathrm{m}^{2}$ biosolids with Eko mixture, while the smallest were in July on the plots with $7.5 \mathrm{~kg} / \mathrm{m}^{2}$ with Roadside mixture $(2.5$ CFU $\times 10^{6} \mathrm{~g}^{-1} \mathrm{~d}$.m. of soil).

The research study of Joniec and Furczak [2007], presented positive effects of sewage sludge on the number of proteolytic bacteria in the second year of the study. Smaller number of proteolytic bacteria in the soil amended with sewage sludge in the first research time was probably caused by the fact that bacteria brought with biosolids into the soil did not find suitable growth conditions in the soil and gradually decayed [Joniec et al. 2012].

The results obtained for the number of amylolytic bacteria show that the sewage sludge dose did not influence this microbial parameter (Figure 1). The largest number of amylolytic microbes was observed in July for the plots with double dose of sludge with Roadside grass mixture (11.6 $\mathrm{CFU} \times 10^{6} \mathrm{~g}^{-1} \mathrm{~d}$.m. of soil), while the lowest results were obtained in October for the plots with a single dose of sludge and Eko grass mixture (1.9 $\mathrm{CFU} \times 10^{6} \mathrm{~g}^{-1} \mathrm{~d}$.m. of soil).

Literature reports that climatic conditions, such as precipitation and temperature, can affect the microbial activity of soil. The amount of soil microorganisms may also have seasonal changes in vegetation period. Increased microbial growth occurs in spring when temperatures rise and in autumn after delivery of soil organic matter in a form of plant residues, which are food for microorganisms.

Rousk et al. [2009] and Su et al. [2004], suggest that soil $\mathrm{pH}$ is a very important parameter which directly determines the possibility of the development of microorganisms, plant growth, bioavailability of nutrients and heavy metals, the biological processes and creating other forms of acidity.

The correlation analysis showed a significant relationships between $\mathrm{pH}$ and the total number of bacteria and the number of Gram-negative bacteria in samples of soil (Table 4). It was found that the increase $\mathrm{pH}$ in soil caused decrease the number of these bacteria.

The preferred conditions for proliferation of bacteria in the soil could be close to neutral $\mathrm{pH}$,

Table 4. The correlation coefficients between selected physic-chemical properties of soil and microbiological parameters $(n=48)$

\begin{tabular}{|l|c|c|c|c|c|}
\hline $\begin{array}{c}\text { The physic-chemical } \\
\text { properties of soil }\end{array}$ & $\begin{array}{c}\text { The total number of } \\
\text { bacteria }\end{array}$ & $\begin{array}{c}\text { The number of } \\
\text { Gram-negative } \\
\text { bacteria }\end{array}$ & $\begin{array}{c}\text { The number of } \\
P \text {. fluorescens }\end{array}$ & $\begin{array}{c}\text { The number of } \\
\text { proteolytic bacteria }\end{array}$ & $\begin{array}{c}\text { The number of } \\
\text { amylolytic bacteria }\end{array}$ \\
\hline $\mathrm{pH}_{\mathrm{H} 2 \mathrm{O}}$ & $-0.31^{*}$ & $-0.33^{*}$ & -0.14 & 0.10 & -0.08 \\
\hline $\mathrm{C}_{\text {org }}$ & 0.09 & 0.18 & -0.18 & -0.12 & -0.08 \\
\hline Total N & -0.27 & 0.11 & -0.08 & -0.03 & 0.08 \\
\hline Available P & 0.18 & 0.18 & 0.28 & 0.28 \\
\hline
\end{tabular}

* significant correlation coefficients for $\mathrm{p}<0.05$. 
providing large amounts of organic matter and minerals as well as small amounts of heavy metals, which do not affect the growth and development of bacteria. Biological properties have been suggested as indicators of the response of soil to a specific contaminants [Jorge-Mardomingo et al. 2013]. Ros et al. [2003] suggest that the microbial parameters are sensitive indicators of stress suffered by soil and its recovery after application on not composed sewage sludge, since microbial activity has a direct influence on the stability and fertility of ecosystem.

\section{CONCLUSIONS}

1. Application of sewage sludge to the soil caused changes in physic-chemical properties of urban soils. The content of organic carbon, available phosphorus and total nitrogen in the soils increased with the dose of sludge, but there was no significant correlation between the number of different groups of microorganisms in the rhizosphere zone.

2. The changes in the levels of the number of proteolytic and Gram-negative microorganisms in the rhizosphere depended on the dose of sludge and mixtures of grasses.

3. With increasing $\mathrm{pH}$ a decrease in of the total number of bacteria and the number of Gramnegative bacteria was observed.

\section{Acknowledgement}

This research was completed with financial support of the project number W/WBiIŚ/14/2014 and S/WBiIŚ/3/2011.

\section{REFERENCES}

1. Bień J., Neczaj E., Worwąg M., Grosser A., Nowak D., Milczarek M., Janik M. 2011. Kierunki zagospodarowania osadów w Polsce po roku 2013. Inżynieria i Ochrona Środowiska, 14, 4, 375-384.

2. Galimska-Stypa R., Małachowska-Jutsz A., Mrozowska J., Zabłocka-Godlewska, E. 1999. Laboratorium z Mikrobiologii Ogólnej i Środowiskowej. Mrozowska J. (Ed.). Wydawnictwo Politechniki Śląskiej, Gliwice.

3. Głażewska-Maniewska R., Maciejewska A., Melech A. 2004. Występowanie bakterii glebowych z rodzaju Arthrobacter spp. w uprawie żyta ozimego oraz ich enzymatyczne i antagonistyczne właściwości. Acta Scientiarum Polonorum Series Agricultura, 3, 1, 129-137.

4. Jankiewicz U. 2010. Bioaktywne metabolity ryzosferowych bakterii Pseudomonas, WodaŚrodowisko-Obszary Wiejskie, 10, 2 (30), 83-92.

5. Jezierska-Tyś S., Frąc M. 2008. Effect of sewage sludge on selected microbiological and biochemical indices of soil fertility in view of domestic and world wide stusied: a review, Acta Agrophysica, 12, 2, 393-407.

6. Joniec J., Furczak J. 2007. Liczebność wybranych grup drobnoustrojów w glebie bielicowej pod uprawą wierzby użyźnionej osadem ściekowym po drugim roku jego działania, Annales Universitatis Mariae Curie-Skłodowska Sectio E Agricultura, 62, 1, 93-104.

7. Joniec J., Furczak J., Baran S. 2012. The importance of sludge microorganisms in nitrogen transformations in podzolic soil amended with sewage sludge, Archives of Environmental Protection, 38, 1, 35-47.

8. Jorge-Mardomingo I., Solver-Rovira P., Casermeiro M.A., de la Cruz M.T., Polo A. 2013. Seasonal changes in microbial activity in a semiarid soil after application of a high dose of different organic amendments, Geoderma, 206, 40-48.

9. Jurkiewicz A., Orłowska E., Anielska T., Godzik B., Turnau K. 2004. The influence of mycorrhiza and EDTA application on heavy metal uptake by different maize varieties. Acta Biologica Cracoviensa Series Botanica, 46, 7-18.

10. Kiryluk A. 2002. Mieszanki traw i osad ściekowy w procesie rekultywacji wysypiska odpadów komunalnych, AR Lublin PTG, Lublin, 85-86.

11. Luo X., Yu S., Zhu Y., Li X. 2012. Trace metal contamination in urban soils in China. Science of the Total Environment, 421-422, 17-30.

12. Ochrona Środowiska: Materiały i opracowania statystyczne. GUS. Warszawa 2013.

13. Ostrowska A., Gawliński S., Szczubiałka Z. 1991. Metody analizy i oceny właściwości gleb i roślin. Katalog. IOŚ, Warszawa.

14. Rodina A. 1968. Mikrobiologiczne metody badania wód. Państwowe Wydawnictwo Rolnicze i Leśne, Warszawa 1968.

15. Ros M., Hernandez M.T., Garcia C. 2003. Soil microbial activity after restoration of semiarid soil by organic amendments, Soil Biology and Biochemistry, 35, 463-469.

16. Rousk J., Brookes P.C., Baath E. 2010. Investigating the mechanisms for the opposing $\mathrm{pH}$ relationships of fungal and bacterial growth in soil, Soil Biology \& Biochemistry, 42, 926-934.

17. Rozporządzenie Ministra Środowiska z dnia 13 lipca 2010 r. w sprawie komunalnych osadów ściekowych (Dz.U. 2010 nr 137 poz. 924). 
18. Sanchez-Monedero M.A., Mondini C., de Nobili M., Leita L., Roig A. 2004. Land application of biosolids. Soil response to different stabilization degree of the treated organic matter. Waste Management, 24, 325-332.

19. Singh R.P., Agrawal M. 2008. Potential benefits and risks of land application of sewage sludge. Waste Management, 28, 347-358.

20. Siuta J. 2003. Uwarunkowania i sposoby przyrodniczego użytkowania osadów ściekowych. Inżynieria Ekologiczna, 9, 7-42.

21. Su D.C., Wong J.W.C., Jagadeesan H. 2004. Implication of rhizospheric heavy metals and nutrients for the growth of alfalfa in sludge amended soil. Chemosphere, 56, 957-965.

22. Tarrason D., Ojeda G., Ortiz O., Alcaniz J.M. 2010. Effect of different types of sludge on soil Microbial Poperties: a field experiment on degraded mediterraneand soils. Pedosphere, 20, 6, 681-681.

23. Wolińska A. 2010. Aktywność dehydrogenazowa mikroorganizmów glebowych i dostępność tlenu w procesie reoksydacji wybranych mineralnych gleb Polski. Acta Agrophysica, 180, Rozpr. Monogr. 3.

24. Wysocki C., Stawicka J. 2005. Trawy na terenach zurbanizowanych. Łąkarstwo w Polsce, 8, 227-236. 